\title{
Pretreatment of cottonseed flakes with proteases and an amylase for higher oil yields
}

\author{
By Fakhriya S. Taha* and Minar M. Hassanein
}

\author{
Fats and Oils Department, National Research Centre \\ El-Bohous St., Dokki, Cairo, Egypt. \\ Corresponding author: Prof. Dr. Fakhriya Sayed Taha, Fats and Oils Department, \\ National Research Centre, El-Bojous St., Dokki, Cairo, Egypt. \\ E-mail : fs- taha@yahoo.com
}

\begin{abstract}
RESUMEN
Pretratamiento de hojuelas de semilla de algodón con proteasas y una amilasa para el incremento del rendimiento de aceite.

En este trabajo se estudió el efecto del pretratamiento con enzimas sobre la extractabilidad del aceite en hojuelas de semilla de algodón. Las enzimas que se investigaron fueron proteasa bacteriana $(\mathrm{Bp})$, papaína $(\mathrm{Pa})$, savinasa $(\mathrm{S})$, temamil $(T)$, pectinasa $(\mathrm{Pe})$ y celulasa $(\mathrm{C})$. Las variables estudiadas durante los experimentos de hidrólisis enzimática fueron: concentración de la enzima, ratio humedad:cantidad de hojuelas y tiempo de hidrólisis. Estos experimentos se realizaron primeramente con una sola enzima y posteriormente con mezclas de enzima formuladas de acuerdo a los resultados obtenidos en los estudios con un solo componente enzimático. Los resultados se evaluaron en función de del incremento relativo de la extractabilidad del aceite, así como de las características del mismo frente a un control realizado con hojuelas sin tratamiento. El pretratamiento con mezclas de enzima resultó en un incremento relativo de la extractabilidad del aceite frente al control mayor del que se registró en los tratamientos con una sola enzima. El análisis estadístico mostró diferencias en extractabilidad significativas (al nivel del $5 \%$ ) entre el control y las distintas mezclas de enzima. El incremento relativo de extractabilidad debido al pretratamiento con mezclas de enzima siguieron el orden S: Pe: Bp $>$ S: Pe>S: C: $\mathrm{Pe}>\mathrm{S}: \mathrm{Bp}>\mathrm{S}: \mathrm{T}>\mathrm{S}: \mathrm{C}>\mathrm{S}: \mathrm{Pa}$ con valores de $44.9 \%, 38.9 \%, 37.1 \%, 34.9 \%$, $30.1 \%$, $28.9 \%$, respectivamente. Las características de los aceites obtenidos aplicando pretratamiento enzimático fueron generalmente similares al control en cuanto a composición de ácidos grasos, acidez, índice de yodo e índice de peróxidos.
\end{abstract}

PALABRAS-CLAVE: Aceite de algodón - Celulasas Extractabilidad - Pectinasas - Proteasas - Tratamiento enzimático.

\section{SUMMARY}

Pretreatment of cottonseed flakes with proteases and an amylase for higher oil yields.

The effect of enzymatic pretreatment of cottonseed flakes on oil extractability was studied. The enzymes investigated included bacterial protease $(\mathrm{Bp})$, papain $(\mathrm{Pa})$, savinase $(\mathrm{S})$, termamyl $(\mathrm{T})$, pectinase $(\mathrm{Pe})$ and cellulase $(\mathrm{C})$. The variables studied during the enzymatic hydrolysis experiments were: enzyme concentration, moisture: cottonseed flakes ratio, and time of hydrolysis. Enzymatic hydrolysis experiments were first carried out with a single enzyme, then with enzyme mixtures formulated according to the results of single enzyme treatments. Results were evaluated based on the relative increase in oil extractability, and some oil characteristics in comparison with untreated cottonseed flakes (control). Pretreatment with enzyme mixtures resulted in a relative increase in oil extractability that was higher than single enzyme pretreatment and the control. Statistical analysis showed a significant difference (at $5 \%$ level) between the control and all enzymatically treated oils as well as among different enzymatically treated oils. The relative increase in oil extractability due to pretreatment with enzyme mixtures were in the following order: $\mathrm{S}: \mathrm{Pe}: \mathrm{Bp}>\mathrm{S}: \mathrm{P}>\mathrm{S}$ : C: $\mathrm{Pe}>\mathrm{S}: \mathrm{Bp}>\mathrm{S}: \mathrm{T}>\mathrm{S}: \mathrm{C}>\mathrm{S}: \mathrm{Pa}$ with values $44.9 \%, 38.9 \%$, $37.1 \%, 34.9 \%, 30.1 \%, 28.9 \%$, respectively. Enzymatic pretreatment of cottonseed flakes resulted in oils with fatty acid composition, acid value, iodine value and peroxide values that were generally comparable to the control.

KEY-WORDS: Amylase - Cellulase - Cottonseed oil Enzymatic treatment - Extractability - Pectinase Proteases.

\section{INTRODUCTION}

With the growing population, the demand for edible oils is constantly increasing especially in developing countries. Along with the increase in demand, there is worldwide interest in healthy foods as well as an awareness of the impact of pollution on human health. This leads to the search for new technologies that are ecofriendly and that would result in healthy food products.

The oilseed industry all over the world is mostly based on the solvent extraction of oil, and generally hexane is the most widely employed solvent. The use of hexane results in the emission of volatile organic compounds (VOCs) that lead to many health hazards (e.g. Carcinogenesis), and cause damage to crops and the environment. The meal resulting from the removal of oil from the oilseed is a rich source of protein. This meal as well as the oil will contain residual hexane that is very difficult to get rid of. Oilseeds need to undergo pretreatments before mechanical expelling or solvent extraction of the oil. The conventional pretreatments of oilseeds may include: dehulling, size reduction and flaking in addition to thermal / hydrothermal treatment, cooking and steaming. The heat treatments involved causes damage to the oil and protein qualities. 
Solvent extraction can be replaced by mechanical expelling of the oil, aqueous extraction or supercritical fluid extraction. These processes yield oil and protein of higher oil qualities, because of the milder treatments employed. Mechanical expelling and aqueous extraction produce smaller quantities of oil than solvent extraction, because an appreciable amount remains trapped in the cake. Super critical fluid extraction is still too costly to be applied in all oil extraction plants. An alternative to heat treatment prior to oil extraction, involves enzymatic treatment. Enzymatic pretreatment of oilseeds is expected to break cell walls and facilitate the flow of oil. In oleaginous seeds the oil is usually found inside the vegetable cell linked with other macromolecules such as proteins, pectin, carbohydrates (Mcglone et al., 1986; Badr and Sitohy, 1992). A cell wall study envisions a cellulosehemicellulose structural domain embedded in a secondary domain consisting of pectic substances, while a third domain consists of covalently cross linked proteins (Carpita and Gibeaut, 1993). Since the structural composition of the cell wall is specific to each oil source, the selection of a suitable enzyme system is critical for efficient oil extraction. Despite the fact that a single type of enzyme may achieve a significant oil recovery, in some cases the combination of several enzymes is often required to degrade a wide range of structural composition in the cell matrix (Chen and Diodsay, 2002).

The use of enzymes as an aid in the oil extraction process has been first recommended by (Hitze et al., 1972), for extraction of oil from corn germ. Moreau et al. (2004) also used enzymatic pretreatment to extract higher yields of corn germ oil. Lanzani et al. (1975) carried out an initial series of preliminary tests on enzymatically hydrolyzing rapeseed, peanuts and sunflower seeds with proteases, cellulases, galactouronide-glicane hydrolase under different conditions of time, temperature, and different concentrations. They reported an increase in oil recovery percentage against total oil under all conditions. Sozulski and Sozulski (1993) and Sengupta and Battacharyya (1996), reported that the quantity of oil extracted after the enzymatic pretreatment of mustard seed and canola was higher than that resulting from untreated seeds. Sitohy et al. (1993) and Dominquez et al. (1993) hydrolyzed sunflower kernels with most of the known effective enzymes as well as multiactivity enzyme complexes and found them to differ in the percentage of extracted oil according to the type of enzyme used.

Several authors examined the effect of enzymatic pretreatment of soybeans for increasing oil extractability. Smith et al. (1993) investigated enzymatic pretreatment followed by mechanical expelling of soybeans. The process parameters were optimized by means of surface methodology. They concluded that enzyme pretreatment enhanced both the amount of extractible oil and oil extractability. A second-order response surface model was developed to predict the expelled oil as a function of six process parameters investigated. Shankar et al. (1997), applied enzymatic hydrolysis in conjunction with flaking (dehulling inherent) and steam conditioning. They reported that it was the best pretreatment compared to other pretreatments they examined.

Bhatnagar and Johari (1987), enzymatically treated cottonseed with several microbial enzymes: proteases, cellulase, and hemicellulase prior to oil extraction. Protease from $\mathrm{H}$. lumuginosa $\mathrm{L}$. resulted in the highest oil extractability. Taha et al. (2002) carried out enzymatic pretreatment of cottonseed flakes with cellulose, hemicellulase, and pectinase. They reported that enzymes, when used individually, resulted in different levels of increasing oil extractability, compared to untreated cottonseed flakes. The highest increase in percent oil extracted was achieved with enzyme mixtures.

Sharma et al. (2002) and Wang et al. (2004) reported positive results for the enzymatic treatment of peanuts preceding oil extraction. Rice bran has been reported to give higher oil yields when stabilized rice bran was treated with enzymes before oil extraction (Sharma et al 2001; Hanmoungjai et al. 2002). Coconut and Shea kernel were also subjected to enzymatic pretreatment which proved to positively increase oil extractability (McGlone et al., 1986; Tano-Debrah and Ohta, 1995; CheMan et al., 1996).

In order to achieve an environmentally friendly process, the enzymatic pretreatment of oilseeds should be followed by any process to extract the oil other than solvent extraction especially when using hexane. Extracting the oil mechanically or by Centrifugation has been suggested by (Smith et al., 1993; Hanmoungjaj et al., 2002).

It became clear that the enzymatic pretreatment of oilseeds followed by hydraulic pressing would result in higher oil yields, improved oil quality, and a cleaner technology. In a previous paper (Taha et al., 2002), investigated the effect of the pretreatment of cottonseed flakes with the enzymes cellulase, hemicellulase, and pectinase. Their results revealed that the relative increase in oil extractability as a result of enzymatic pretreatment with enzymes and their mixtures were in the following order: Pectinase-cellulase $>$ pectinase $>$ pectinase cellulase - hemicellulase $>$ cellulase $>$ hemicellulase.

The present investigation is a continuation of the work on cottonseed flakes, where the effect of several proteases (Bacterial protease, papain and Savinase) as well as --amylase (Termamyl) on oil yield and quality was investigated. The enzymatic reaction was carried out under different enzyme concentrations $(1,2$, and 3 percent), at different moistures: cottonseed flakes ratio (1: $5.5,1: 7,1$ : $10.5 \mathrm{w}: \mathrm{w})$, and for 3 and $6 \mathrm{~h}$. In order to determine the effect of the different enzymes on the parameters investigated, single enzymes and the mixtures formulated with them were used. Enzymatic treatment was followed by solvent extraction of the oil for convenience (solvent extraction is more convenient than hydraulic 
pressing). In a coming study, and owing to the optimum results achieved in this work, the optimum enzymatic conditions will be applied on cottonseed flakes followed by hydraulic pressing to reach the original goal of a clean technology.

\section{MATERIALS AND METHODS}

Cottonseed flakes (Gossypium barbadence) were supplied by El- Minya Ginning Company, ElMinya, Egypt.

Enzymes Papain and Bacterial protease are products of SIGMA, USA. Enzymes Savinase and Termamyl are products of NOVOZYME, Denmark. (offered kindly as free samples).

Standard methyl esters were products of SIGMA, USA.

\subsection{Enzymatic treatment of cottonseed flakes.}

A calculated amount of water was added to the flakes to reach the desired Moisture content $(\mathrm{M})$ : Cottonseed flakes(CSF) ratio (w/w ratio), mixed well, the enzyme was then added, the mixture was continuously agitated on a magnetic stirrer, while the $\mathrm{pH}$ was being adjusted, continuously for 15-20 min to ensure the stability of $\mathrm{pH}$. The flask containing the reaction mixture was placed in a thermostatic water bath adjusted to the optimum temperature for each enzyme. Shaking continued for a predetermined time. At the end of the experiment the temperature was raised to $105^{\circ} \mathrm{C}$ for $30 \mathrm{~min}$ and the $\mathrm{pH}$ dropped to 4.0 to stop the activity of the enzyme. The hydrolyzed flakes were then filtered through (Whatman no.1) filter paper, left in the open air for about $3 \mathrm{~h}$ and then placed in a draft air oven at $60^{\circ} \mathrm{C}$ for $24 \mathrm{~h}$. The dried flakes were then ground to pass 60 mesh screens and subjected to oil extraction using $n$-hexane in a soxhlet apparatus. The extraction was carried out for $12 \mathrm{~h}$, dried at $60{ }^{\circ} \mathrm{C}$; the meal was reground, and re-extracted with a fresh quantity of n-hexane for an additional twelve hours. The two hexane extracts were combined, dried over anhydrous sodium sulphate, filtered and evaporated to near dryness in a rotary evaporator, then dried in a vacuum oven at $60^{\circ} \mathrm{C}$ overnight, till constant weight, and percent extracted oil was calculated. Variables investigated in this study include: Enzyme concentration 1, 2, and 3 percent were calculated as percent of sample weight, M: CSF ratio w/w, 5.5:1, 7:1, 10.5:1, and duration of hydrolysis 3 and $6 \mathrm{~h}$. Other conditions such as temperature and $\mathrm{pH}$ used were those recommended by the manufacturers. For papain $25^{\circ} \mathrm{C}$ and $\mathrm{pH} 6.2$; bacterial protease $37^{\circ} \mathrm{C}$ and $\mathrm{pH}$ 7.5; savinase $55^{\circ}-60^{\circ} \mathrm{C}$ and $\mathrm{pH} 8-11$; Termamyl $85^{\circ}-115^{\circ} \mathrm{Cand} \mathrm{pH}$ 5.6-6.6. A control representing untreated CSF that was directly subjected to oil extraction with n-hexane was also carried out.

This experiment was repeated four times for each enzyme or enzyme mixture under the investigated conditions.

\subsection{Formulation of enzyme mixtures}

Enzyme mixtures were formulated using bacterial protease $(\mathrm{Bp})$, papain $(\mathrm{Pa})$, savinase $(\mathrm{S})$, termamyl $(T)$, cellulase $(C)$, and pectinase $(P e)$.

Formulated enzyme mixtures are represented in Table 1.

\subsection{Fatty acid composition}

The component fatty acids of the oil samples extracted from enzymatically treated cottonseed flakes, together with a control sample resulting from untreated cottonseed flakes were converted to their methyl esters by esterification according to (Christie 1973). The reaction was monitored with the help of TLC to ensure complete conversion to methyl esters. The mixed methyl esters of each sample were subjected to gas liquid chromatographic (GLC) analysis. A Hewlett Packard (HP) Model 6890 Gas Chromatograph was employed for the analysis under the following conditions: INNO wax capillary column (polyethylene glycol), $30.0 \mathrm{~m} \times 530 \mu \mathrm{m}$, film thickness $1.0 \mu \mathrm{m}$; column was operated isothermally at $280^{\circ} \mathrm{C}$; injection temperature $280^{\circ} \mathrm{C}$; split ratio 8:1; split flow $120 \mathrm{ml}$; gas saver $20 \mathrm{ml} / \mathrm{min}$; and carrier gas $\mathrm{N}_{2}$, with flow rate 15 $\mathrm{ml} / \mathrm{min}$; FID detector temperature ${ }^{2} 280^{\circ} \mathrm{C}$; hydrogen flow rate $30 \mathrm{ml} / \mathrm{min}$; and air flow rate $300 \mathrm{ml} / \mathrm{min}$. Peak areas were determined by electronic integrator and percentage composition of fatty acids automatically calculated. A standard mixture of fatty acids methyl esters (methyl myristate, methyl palmitate, methyl stearate, methyl oleate, methyl linoleate, and methyl linolenate) was also chromatographed under the same operating conditions. The entity of the peaks was achieved through comparison of the retention times with those of standards.

\subsection{Oil analysis}

Moisture, acid value, iodine value, and peroxide value were determined according to standard methods of analysis of AOCS (1998).

Table 1

Formulation of enzyme mixtures.

\begin{tabular}{|c|c|c|c|}
\hline Treatment & Enzyme mixture & $\mathrm{pH}$ & Temperature \\
\hline 1 & $\begin{array}{l}\text { S: BP } \\
(1: 1)\end{array}$ & 8 & 40 \\
\hline 2 & $\begin{array}{l}\text { S: Pa } \\
(1: 1)\end{array}$ & 7 & 30 \\
\hline 3 & $\begin{array}{l}\mathrm{S}: \mathrm{T} \\
(1: 1)\end{array}$ & 7 & 70 \\
\hline 4 & $\begin{array}{l}\text { S: C } \\
(1: 1)\end{array}$ & 6.5 & 45 \\
\hline 5 & $\begin{array}{l}\mathrm{S}: \mathrm{Pe} \\
(1: 1)\end{array}$ & 6 & 35 \\
\hline 6 & $\begin{array}{c}\text { S: Pe: BP } \\
(0.66: 0.66: 0.66)\end{array}$ & 6.5 & 50 \\
\hline 7 & $\begin{array}{c}\text { S: Pe: C } \\
0.66: 0.66: 0.66)\end{array}$ & 6.5 & 50 \\
\hline
\end{tabular}

* These mixtures were carried out usin $2 \%$ enzyme concentration, M: CSFratio 7: 1, for $6 \mathrm{hr}$ 
Experiments were carried out in four replicates, and analyses of all samples in duplicate.

\subsection{Statistical analysis}

The experiment followed completely randomized design (CRD). The obtained data were subjected to analysis of variance (ANOVA) according to (Snedcor and Cochran 1980). Duncan's Multiple Range test was used to compare between means of treatments according to (Walter and Duncan 1969) at probability 5 percent.

Correlation studies were done on an HP home computer, using excel program.

\section{RESULTS AND DISCUSSION}

This work is the continuation of a previous paper (Taha et al., 2002) where the effect of the enzymes $\mathrm{C}, \mathrm{HC}$, and Pe on the oil extractability from CSF was studied. Results indicated that enzymes $\mathrm{C}$ and $\mathrm{Pe}$ exhibited a significant effect on the oil extractability from CSF, while $\mathrm{HC}$ was less efficient. Furthermore, a mixture of $C$ and $P e$ in a 1:1 ratio $(\mathrm{w} / \mathrm{w})$ resulted in higher oil extraction than the two single enzymes. In the present work, since the lipids are sometimes bound in the form of lipoproteins and liposaccharide complexes (Shankar et al.1997), it was worth while to investigate the effect of the proteases $(\mathrm{Bp}, \mathrm{Pa}$, and $S$ ) and a $\alpha$-amylase (T) on the oil extractability of CSF. Mixtures from the enzymes studied in our previous paper $(\mathrm{C}, \mathrm{HC}, \mathrm{Pe})$ together with the enzymes under investigation $(\mathrm{Bp}, \mathrm{Pa}, \mathrm{S}, \mathrm{T})$ were formulated and their effect on the oil extractability of CSF was studied.

\subsection{Effect of pretreatment of cottonseed flakes with bacterial protease on oil extraction}

Table 2. Shows the results of enzymatically hydrolyzing CSF with $\mathrm{Bp}$ at $(1,2$, and 3 percent enzyme concentration), M: CSF ratio (5.5: 1, 7: 1, and 10.5: $1 \mathrm{w} / \mathrm{w})$, for 3 and $6 \mathrm{~h}$. All treatments resulted in an increase in the extracted oil from CSF compared to the control (oil from untreated CSF). There was a significant difference at (5\% level) among all treatments and the control. Significant and non significant difference between treatments can also be detected from Table 2. Only the treatment of CSF with $3 \% \mathrm{Bp}$, at M: CSF ratio $7: 1$, for $6 \mathrm{~h}$ showed a highly significant difference with all other treatments. Oil extracted from control sample was $20.5 \%$, while enzymatic treatment with Bp under the different conditions of the investigation resulted in extracted oil between $21.5-25.9 \%$. The highest relative increase in oil extractability $26.1 \%$ was achieved at $3 \%$ enzyme concentration, $\mathrm{M}$ : CSF ratio $7: 1$ and duration of 6 h. Treatments with $\mathrm{Bp}$ at $2 \%$ and $3 \%$ concentration, at $7: 1 \mathrm{M}$ : CSF ratio, for 3 and $6 \mathrm{~h}$ resulted in a percent increase in oil extractability between 21.6 and $22.6 \%$. Treatment with $1 \%$ enzyme concentration, $10: 1$ and 5.5: $1 \mathrm{M}$ : CSF ratio, for $3 \mathrm{~h}$ and $6 \mathrm{~h}$ also resulted in a

Table 2

Effect of bacterial protease pretreatment of cottonseed flakes on oil extractability.

\begin{tabular}{ccccc}
\hline $\begin{array}{c}\text { Enzyme } \\
\text { conc.(\%) }\end{array}$ & $\begin{array}{c}\text { Time } \\
\text { (hrs) }\end{array}$ & $\begin{array}{c}\text { M : CSF } \\
\text { ratio }\end{array}$ & $\begin{array}{c}\text { Extracted oil } \\
(\%)\end{array}$ & $\begin{array}{c}\text { Increase in oil } \\
\text { extractability (\%) }\end{array}$ \\
\hline 1 & 3 & $5.5: 1$ & $21.49 \pm 0.37 \mathrm{~g}$ & 4.77 \\
1 & 3 & $7: 1$ & $23.13 \pm 0.69 \mathrm{f}$ & 12.73 \\
1 & 3 & $10.5: 1$ & $24.88 \pm 0.64 \mathrm{bc}$ & 21.29 \\
2 & 3 & $5.5: 1$ & $22.92 \pm 0.60 \mathrm{f}$ & 11.71 \\
2 & 3 & $7: 1$ & $24.96 \pm 0.38 \mathrm{bc}$ & 21.67 \\
2 & 3 & $10.5: 1$ & $23.91 \pm 0.83 \mathrm{de}$ & 13.26 \\
3 & 3 & $5.5: 1$ & $23.24 \pm 0.51 \mathrm{ef}$ & 13.26 \\
3 & 3 & $7: 1$ & $25.16 \pm 0.49 \mathrm{~b}$ & 22.64 \\
3 & 3 & $10.5: 1$ & $24.39 \pm 0.76 \mathrm{~cd}$ & 18.85 \\
1 & 6 & $5.5: 1$ & $25.02 \pm 0.47 \mathrm{bc}$ & 21.92 \\
1 & 6 & $7: 1$ & $22.83 \pm 0.68 \mathrm{f}$ & 11.28 \\
1 & 6 & $10.5: 1$ & $22.03 \pm 0.68 \mathrm{~g}$ & 7.38 \\
2 & 6 & $5.5: 1$ & $23.22 \pm 0.48 \mathrm{ef}$ & 13.16 \\
2 & 6 & $7: 1$ & $25.10 .5 \pm 0.55 \mathrm{bc}$ & 22.33 \\
2 & 6 & $10.5: 1$ & $24.39 \pm 0.35 \mathrm{c} \mathrm{d}$ & 18.85 \\
3 & 6 & $5.5: 1$ & $21.99 \pm 0.47 \mathrm{~g}$ & 7.18 \\
3 & 6 & $7: 1$ & $25.88 \pm 0.56 \mathrm{a}$ & 26.11 \\
3 & 6 & $10.5: 1$ & $23.35 \pm 0.28 \mathrm{ef}$ & 13.8 \\
Control (untreated flakes) & & $20.52 \pm 0.58 \mathrm{~h}$ & \\
\hline
\end{tabular}

$\mathrm{M}=$ moisture, $\mathrm{CSF}=$ cottonseed flakes. Means with different letters within each column are significant means followed by the same alphabetical letters are not significantly different at $5 \%$ level and means without letters are not significant. SD : Calculated from values of four replicates. 
percent increase in oil extractability of 21 and $22 \%$, respectively. Treatment of CSF with Bp under the other investigated conditions gave lower relative increase in oil extractability.

\subsection{Effect of pretreatment of cottonseed flakes with papain on oil extraction}

Results in Table 3. reveal that the pretreatment of CSF with $\mathrm{Pa}$ enzyme at different enzyme concentrations, M: CSF ratio, and different times, produces that highest quantity of extracted oil ca.25\% was achieved at $3 \%$ Pa concentration, $5.5: 1 \mathrm{M}$ : CSF ratio, and $3 \mathrm{~h}$ of hydrolysis. All treatments showed a significant difference at (5\% level) compared to the control, except for treatment with $\mathrm{Pa}$ at $1 \%$ enzyme concentration, 5.5:1 M: CSF ratio, for $3 \mathrm{~h}$ which showed no significant difference with control. Significant and non significant differences between treatments can be seen clearly in Table 3. Treatment with $\mathrm{Pa}$ under all the investigated conditions resulted in oil extraction from 22 to $25 \%$. The highest relative increase in oil extractability ca. $23 \%$ was attained when enzymatic hydrolysis was carried out at $3 \%$ enzyme concentration, 5.5: $1 \mathrm{M}$ : CSF ratio and hydrolysis continued for $3 \mathrm{~h}$. Other values of relative increase in oil extractability ranged from $7.25-22.7 \%$.

\subsection{Effect of pretreatment of cottonseed flakes with savinase on oil extraction}

Table 4. Indicates that pretreatment of CSF with $S$ achieved the highest yield of extracted oil $26.2 \%$ at 1\% enzyme concentration, $7: 1 \mathrm{M}$ : CSF ratio, and time of $3 \mathrm{~h}$. There was a significant difference at (5\% level) between the oil extracted under the previous conditions and the control. There was also a significant difference between the oil extracted at $3 \%$ enzyme concentration, 5.5: $1 \mathrm{M}$ : CSF ratio, for 6 $\mathrm{h}$ and the control oil. As seen from the table, there was no significant difference between other treatments and the control, as well as no significant difference among most of the treatments. The highest relative increase in oil extractability reached ca. $27.7 \%$, other values of relative increase in oil extractability for other treatments ranged from 8.0$23.9 \%$.

\subsection{Effect of pretreatment of cottonseed flakes with termamyl on oil extraction}

Depicts the way in which the pretreatment of CSF with enzyme $T$ prior to oil extraction resulted in the highest relative increase in oil extractability of $25 \%$. This was achieved under the following conditions: 2 and $3 \%$ enzyme concentration, 5.5: $1 \mathrm{M}$ : CSF ratio with a treatment duration of $6 \mathrm{~h}$. 3\% enzyme concentration, 7: $1 \mathrm{M}$ : CSF ratio, for $3 \mathrm{~h}$ also resulted in $25 \%$ oil extractability. Naturally there was no significant difference at ( $5 \%$ level) among these three treatments, but there was a significant difference among them and the other treatments compared to the control. All treatments exhibited a significant difference compared to the control. The relative increase in oil extractability resulting from the different treatments ranged between $7.78-23.94 \%$.

Table 3

Effect of papain pretreatment of cottonseed flakes on oil extractability.

\begin{tabular}{ccccc}
\hline $\begin{array}{c}\text { Enzyme } \\
\text { conc.(\%) }\end{array}$ & $\begin{array}{c}\text { Time } \\
\text { (hrs) }\end{array}$ & $\begin{array}{c}\text { M : CSF } \\
\text { ratio }\end{array}$ & $\begin{array}{c}\text { Extracted oil } \\
(\%)\end{array}$ & $\begin{array}{c}\text { Increase in oil } \\
\text { extractability (\%) }\end{array}$ \\
\hline 1 & 3 & $5.5: 1$ & $22.33 \pm 0.34 \mathrm{f}$ & 8.83 \\
1 & 3 & $7: 1$ & $24.01 \pm 0.31 \mathrm{c}$ & 17.01 \\
1 & 3 & $10: 1$ & $22.01 \pm 0.67 \mathrm{e}$ & 7.25 \\
2 & 3 & $5.5: 1$ & $24.58 \pm 0.33 \mathrm{bc}$ & 19.8 \\
2 & 3 & $7: 1$ & $22.42 \pm 0.32 \mathrm{e}$ & 9.23 \\
2 & 3 & $10: 1$ & $23.11 \pm 0.45 \mathrm{~d}$ & 12.61 \\
3 & 3 & $5.5: 1$ & $25.19 \pm 0.43 \mathrm{a}$ & 22.74 \\
3 & 3 & $7: 1$ & $23.05 \pm 0.47 \mathrm{~d}$ & 12.19 \\
3 & 3 & $10: 1$ & $22.37 \pm 0.50 \mathrm{e}$ & 8.99 \\
1 & 6 & $5.5: 1$ & $23.13 \pm 0.56 \mathrm{~d}$ & 12.7 \\
1 & 6 & $7: 1$ & $24.21 \pm 0.50 \mathrm{c}$ & 17.98 \\
1 & 6 & $10: 1$ & $23.14 \pm 0.60 \mathrm{~d}$ & 12.76 \\
2 & 6 & $5.5: 1$ & $23.27 \pm 0.04 \mathrm{~d}$ & 13.4 \\
2 & 6 & $7: 1$ & $25.07 \pm 0.34 \mathrm{ab}$ & 22.17 \\
2 & 6 & $10: 1$ & $23.23 \pm 0.54 \mathrm{~d}$ & 13.23 \\
3 & 6 & $5.5: 1$ & $24.22 \pm 0.40 \mathrm{c}$ & 18.03 \\
3 & 6 & $7: 1$ & $25.04 \pm 0.30 \mathrm{ab}$ & 22.05 \\
3 & 6 & $10: 1$ & $23.18 \pm 0.53 \mathrm{~d}$ & 12.98 \\
Control (untreated flakes) & & $20.52 \pm 0.58 \mathrm{f}$ & \\
\hline
\end{tabular}

$\mathrm{M}=$ moisture, CSF = cottonseed flakes. Means with different letters within each column are significant, 
Table 4

Effect of Savinase pretreatment of cottonseed flakes on oil extractability.

\begin{tabular}{ccccc}
\hline $\begin{array}{c}\text { Enzyme } \\
\text { conc.(\%) }\end{array}$ & $\begin{array}{c}\text { Time } \\
\text { (hrs) }\end{array}$ & $\begin{array}{c}\text { M : CSF } \\
\text { ratio }\end{array}$ & $\begin{array}{c}\text { Extracted oil } \\
\mathbf{( \% )}\end{array}$ & $\begin{array}{c}\text { Increase in oil } \\
\text { extractability (\%) }\end{array}$ \\
\hline 1 & 3 & $5.5: 1$ & $22.18 \pm 0.47$ def & 8.09 \\
1 & 3 & $7: 1$ & $26.21 \pm 0.27 \mathrm{a}$ & 27.73 \\
1 & 3 & $10: 1$ & $23.47 \pm 0.53 \mathrm{bcde}$ & 14.351 \\
2 & 3 & $5.5: 1$ & $23.85 \pm 0.69 \mathrm{abcde}$ & 16.21 \\
2 & 3 & $7: 1$ & $25.05 \pm 0.81 \mathrm{abc}$ & 22.09 \\
2 & 3 & $10: 1$ & $22.39 \pm 0.88 \mathrm{cdef}$ & 9.11 \\
3 & 3 & $5.5: 1$ & $22.15 \pm 0.55 \mathrm{def}$ & 7.93 \\
3 & 3 & $7: 1$ & $23.25 \pm 0.49 \mathrm{bcdef}$ & 13.29 \\
3 & 3 & $10: 1$ & $21.96 \pm 0.68 \mathrm{def}$ & 7.01 \\
1 & 6 & $5.5: 1$ & $23.08 \pm 0.67 \mathrm{abcdef}$ & 12.45 \\
1 & 6 & $7: 1$ & $22.63 \pm 1.37 \mathrm{cdef}$ & 10.3 \\
1 & 6 & $10: 1$ & $21.41 \pm 0.64$ ef & 4.32 \\
2 & 6 & $5.5: 1$ & $24.45 \pm 0.51 \mathrm{abcd}$ & 19.13 \\
2 & 6 & $7: 1$ & $21.73 \pm 0.64 \mathrm{def}$ & 5.91 \\
2 & 6 & $10: 1$ & $22.55 \pm 0.48 \mathrm{cdef}$ & 9.91 \\
3 & 6 & $5.5: 1$ & $25.43 \pm 0.61 \mathrm{ab}$ & 23.95 \\
3 & 6 & $7: 1$ & $22.18 \pm 0.84 \mathrm{def}$ & 8.08 \\
3 & 6 & $10: 1$ & $23.29 \pm 0.64 \mathrm{bcdef}$ & 13.49 \\
Control (untreated flakes) & & $20.52 \pm 0.64 \mathrm{f}$ & \\
\hline
\end{tabular}

$\mathrm{M}=$ moisture, CSF = cottonseed flakes. Means with different letters within each column are significant,

means followed by the same alphabetical letters are not significantly different at $5 \%$ level and means without letters are not significant. SD : Calculated from values of four replicates.

\subsection{Effect of pretreatment of cottonseed flakes with enzyme mixtures on percent increase in oil extractability}

From the above results it can be concluded that optimum oil extractability was achieved with the four investigated enzymes in the following order $\mathrm{S}>\mathrm{Bp}$ $>\mathrm{T}>\mathrm{Pa}$.

Enzyme mixtures were formulated with the $S$ enzyme being the common partner in all mixtures since the results of single enzymatic reactions revealed that this enzyme produced the greatest amount of oil extraction. Enzyme mixtures are formulated as shown Table 1. Results of pretreatment of CSF with enzyme mixtures are demonstrated in Figure 1. Mixture S: Pe: Bp resulted in the highest relative increase in extracted oil reaching $44.9 \%$, as compared to the control. Relative increases in extracted oil from CSF when pretreated with enzyme mixtures were in the following order: $\mathrm{S}: \mathrm{Pe}: \mathrm{Bp}>\mathrm{S}$ $: \mathrm{Pe}>\mathrm{S}: \mathrm{C}: \mathrm{Pe}>\mathrm{S}: \mathrm{Bp}>\mathrm{S}: \mathrm{T}>\mathrm{S}: \mathrm{C}>\mathrm{S}: \mathrm{Pa}$ with values of $44.9 \%, 39.7 \%, 38.9 \%, 37.1 \%, 34.9 \%$, $30.1 \%, 28.9 \%$, respectively.

From the previous results it is obvious that when using single enzymes for the enzymatic pretreatment of cottonseed flakes, the proteases resulted in higher oil yields. Investigated proteases S, Bp, and Pa gave relative increases in oil extractability over the control oil of $28 \%, 26 \%$, and $23 \%$, respectively. While single enzymes $\mathrm{T}, \mathrm{Pe}$, and $\mathrm{C}$ resulted in $24 \%, 23 \%$, and $10.5 \%$ relative increase in oil extractability, respectively, (results for $\mathrm{C}$ and $\mathrm{Pe}$ are from our previous study Taha et al. 2002). Bahatnagar and Johari (1987), enzymatically extracting cottonseed oil with several proteases from microorganisms as well as cellulase and hemicellulase, reported that the protease from $H$.lanuginosa-l gave the highest oil yield compared to other enzymes and the control. Other investigators reporting proteases to yield higher oil quantities than other enzymes studied include: Hanmoungjiai et al (2002), working with rice bran; Santas and Ferrari (2005), working with soybean; Sharma et al. (2002), working with peants; and Lanzani et al. (1975), working with rapeseed and peanut; and Sitohy et al. (1993) working with sunflower.

In an attempt to explain the fact that proteases can be more effective than carbohydrases and pectinases although the cell wall is made up of

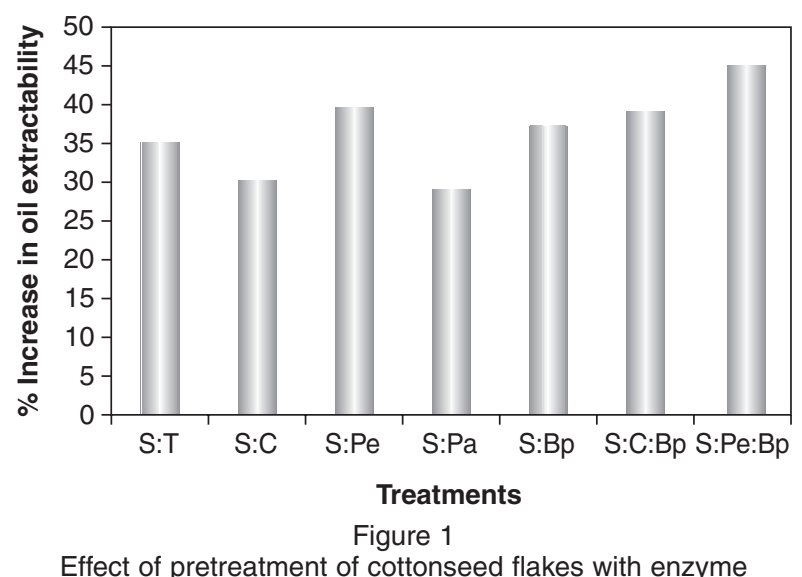

Effect of pretreatment of cottonseed flakes with enzyme mixtures on increase in oil extractability. 
cellulose, hemicellulose, lignin and pectin (Snyder and Kwon 1987), other authors report the presence of protein in the cell wall. It is worthy to note that the main feature of oilseed cotyledon cells is the existence of discrete cellular organelles called lipid and protein bodies which contain all the oil and protein in the grain. It is also important to know that oil bodies contain abundant proteins called oleosins which seem to play an important role in stabilizing these bodies. Proteolytic enzymes can also affect the cytoplasmic network which is largely composed of protein in oilseeds, or break up the lipid protein complexes when present (Rosenthal et al.1996).

The increase in relative oil extractability due to the use of mixed enzymes over single enzymes can be depicted from our results where treatment 6 ( $S$ : Pe: $\mathrm{Bp})$ resulted in $44 \%$ relative increase in oil extractability while $\mathrm{S}, \mathrm{Pe}, \mathrm{Bp}$ when used as single enzymes gave $28 \%, 23 \%, 26 \%$, respectively. The work of many authors confirm this finding (Lanzani et al.1975; Che Man et al.1996; Sharma et al. 2001; Hanmoungjiai et al.2001; Taha et al 2002). These results are logical since the oil cell wall is made up of cellulose, hemicellulose, pectin, lignin and protein. Therefore the treatment of the cells of the oilseeds with several of the specific enzymes needed to break up these constituents will free more oil (Rosenthal et al. 1996)

\subsection{Results regression}

Figures 2 a,b,c and d depict the fact that that the relationship of enzyme concentration versus the increase in oil extractability have a linear correlation, with fair regression coefficient which ranged from 0.92 to 0.99 except in the following cases: figure 2a., savinase enzyme at these conditions of treatment, 3h, 10.5: $1 \mathrm{M}$ : CSF and 6h, 10.5: $1 \mathrm{M}$ : CSF; figure2b., papain enzyme at 3h, 7:1 M: CSF and 3h, 10.5:1 M: CSF; figure 2c., savinase enzyme at 3h, 10.5:1 M: CSF and 6h, 7:1 M: CSF; figure 2d. Termamyl enzyme at 3h, 7:1 M: CSF, 3h, 5.5:1 M: CSF, 6h, 7: $1 \mathrm{M}$ : CSF. These cases are obviously non-linear relationships which were best fitted by using least square method and their perfect regression coefficient is higher than 0.9999 .

\subsection{Effect of enzymatic pretreatment of cottonseed flakes on the characteristics of the extracted oil}

Results in Table 6 reveal the effect of pretreatment of CSF with single enzymes under optimum conditions, as determined by the highest relative increase in extracted oil, on some oil characteristics. Table 6 also indicates the effect of pretreatment with enzyme mixtures (under the conditions given in table 1) on some characteristics of the extracted oil.

\subsubsection{Iodine value (IV)}

The IV indicates the degree of unsaturation of oils. The IV of the oils resulting from most of the emzymatic treatments (Table 6) showed no

Table 5

Effect of termamyl pretreatment of cottonseed flakes on oil extractability.

\begin{tabular}{ccccc}
\hline $\begin{array}{c}\text { Enzyme } \\
\text { conc.(\%) }\end{array}$ & $\begin{array}{c}\text { Time } \\
\text { (hrs) }\end{array}$ & $\begin{array}{c}\text { M : CSF } \\
\text { ratio }\end{array}$ & $\begin{array}{c}\text { Extracted oil } \\
(\%)\end{array}$ & $\begin{array}{c}\text { Increase in oil } \\
\text { extractability (\%) }\end{array}$ \\
\hline 1 & 3 & $5.5: 1$ & $23.71 \pm 0.71 \mathrm{bcd}$ & 15.56 \\
1 & 3 & $1: 7$ & $23.91 \pm 0.73 \mathrm{bcd}$ & 16.48 \\
1 & 3 & $1: 10.5$ & $22.318 \pm 1.042 \mathrm{fg}$ & 8.76 \\
2 & 3 & $5.5: 1$ & $24.29 \pm 0.42 \mathrm{bc}$ & 18.39 \\
2 & 3 & $1: 7$ & $22.39 \pm 0.81 \mathrm{fg}$ & 9.15 \\
2 & 3 & $1: 10.5$ & $22.48 \pm 0.82 \mathrm{efg}$ & 9.55 \\
3 & 3 & $5.5: 1$ & $22.12 \pm 0.54 \mathrm{~g}$ & 7.78 \\
3 & 3 & $1: 7$ & $25.36 \pm 0.60 \mathrm{a}$ & 23.56 \\
3 & 3 & $1: 10.5$ & $23.45 \pm 0.55 \mathrm{cde}$ & 14.25 \\
1 & 6 & $5.5: 1$ & $22.95 \pm 0.76 \mathrm{defg}$ & 11.84 \\
1 & 6 & $1: 7$ & $22.45 \pm 0.70 \mathrm{fg}$ & 9.41 \\
1 & 6 & $1: 10.5$ & $24.24 \pm 0.81 \mathrm{bc}$ & 18.14 \\
2 & 6 & $5.5: 1$ & $25.35 \pm 0.98 \mathrm{a}$ & 23.52 \\
2 & 6 & $1: 7$ & $24.52 \pm 1.05 \mathrm{ab}$ & 19.47 \\
2 & 6 & $1: 10.5$ & $23.23 \pm 0.60 \mathrm{def}$ & 13.22 \\
3 & 6 & $5.5: 1$ & $25.43 \pm 0.79 \mathrm{a}$ & 23.94 \\
3 & 6 & $1: 7$ & $23.00 \pm 0.78 \mathrm{defg}$ & 12.11 \\
3 & 6 & $1: 10.5$ & $22.43 \pm 0.87 \mathrm{fg}$ & 9.33 \\
Control (untreated flakes) & & $20.52 \pm 0.58 \mathrm{~h}$ & \\
\hline
\end{tabular}

$\mathrm{M}=$ moisture, $\mathrm{CSF}=$ cottonseed flakes. Means with different letters within each column are significant, 

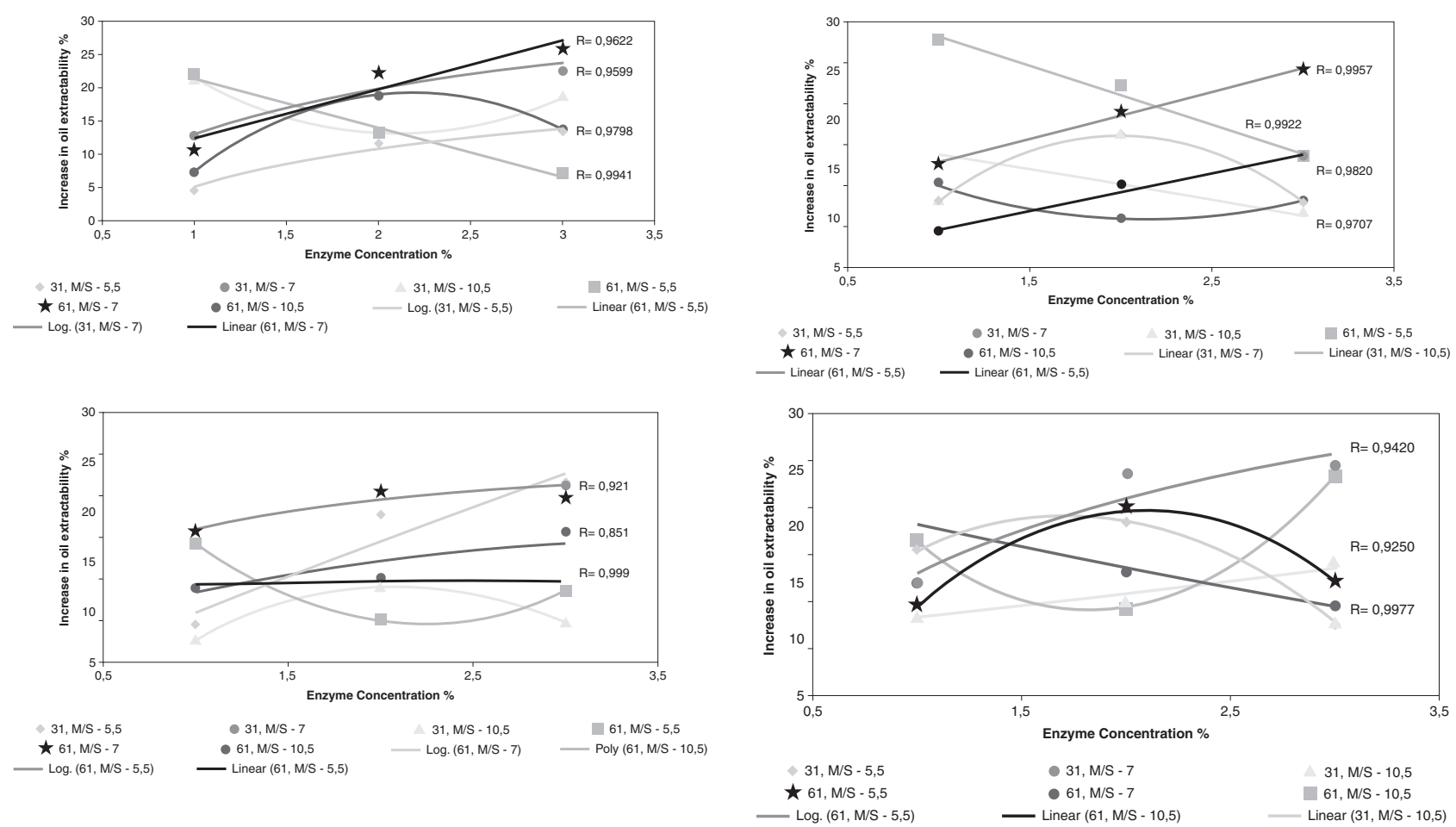

Figura 2

a) Effect of bacterial protease concentration on increase in oil extractability; b) Effect of papain concentration on increase in oil extractability; c) Effect of savinase concentration on increase in oil extractability; d) Effect of Termamyl Enzyme Concentration on Cotton Seed Oil Extractability \%.

significant difference (at 5\% level) when compared to the control oil (untreated). The oils resulting from the pretreatment with $\mathrm{S}$ and $\mathrm{Bp}$ exhibited a significant difference compared to the control and other treatments. The IV of the control oil was 98.50, while oils resulting from most of the treatments were less than the control with IV ranging from 95.6 to 98.6. The IV of the oils resulting from pretreatment with enzyme mixtures S: Pe and S: Bp: Pe was slightly higher (99.0) than the control.

\subsubsection{Acid value (AV)}

The oil hydrolysis (as indicated by the AV) as a result of pretreatment with single enzymes or their mixtures indicate that there was no or very slight hydrolysis (Table 6). There was no significant difference (at $5 \%$ level) between treatments and the control nor among treatments. Only the AV of the oil resulting from treatment 5 . Showed a significant difference with that of the control oil and oils resulting from other treatments.

Table 6

Effect of Enzymatic Pretreatment of Cottonseed Flakes on Some Characteristics of the Extracted Oil.

\begin{tabular}{lccc}
\hline \multicolumn{1}{c}{ Enzyme Treatment } & lodine Value & Acid Value & Peroxide Value \\
\hline non (control) & $98.50 \pm 0.1 \mathrm{ab}$ & $4.93 \pm 0.2 \mathrm{abc}$ & $0.0 \mathrm{~h}$ \\
Bacterial protease & $95.62 \pm 0.12 \mathrm{~d}$ & $5.30 \pm 0.09 \mathrm{a}$ & $0.28 \pm 0.13 \mathrm{~g}$ \\
Savinase & $96.03 \pm 0.20 \mathrm{~cd}$ & $5.27 \pm 0.49 \mathrm{a}$ & $1.17 \pm 0.12 \mathrm{f}$ \\
Papain & $97.27 \pm 0.16 \mathrm{bc}$ & $4.65 \pm 0.10 \mathrm{~cd}$ & $1.27 \pm 0.14 \mathrm{ef}$ \\
Termamyl & $97.70 \pm 0.14 \mathrm{ab}$ & $5.18 \pm 0.12 \mathrm{a}$ & $1.63 \pm 0.08 \mathrm{~cd}$ \\
Savinase : Bacterial protease (1:1) & $98.57 \pm 0.14 \mathrm{ab}$ & $5.13 \pm 0.12 \mathrm{ab}$ & $1.18 \pm 0.08 \mathrm{f}$ \\
Savinase : Papain $(1: 1)$ & $98.48 \pm 0.26 \mathrm{ab}$ & $4.9 \pm 0.13 \mathrm{abc}$ & $1.88 \pm 0.09 \mathrm{~b}$ \\
Savinase : Termamyl (1:1) & $98.30 \pm 0.11 \mathrm{ab}$ & $4.80 \pm 0.09 \mathrm{bd}$ & $1.53 \pm 0.05 \mathrm{~d}$ \\
Savinase : Cellulase $(1: 1)$ & $97.62 \pm 0.12 \mathrm{ab}$ & $5.13 \pm 0.1 \mathrm{ab}$ & $1.35 \pm 0.05 \mathrm{e}$ \\
Savinase :Pectinase $(1: 1)$ & $99.07 \pm 0.48 \mathrm{a}$ & $4.57 \pm 0.12 \mathrm{~d}$ & $1.92 \pm 0.08 \mathrm{~b}$ \\
Savinase:Cellulase:Pectinase & $96.90 \pm 0.89 \mathrm{bcd}$ & $4.97 \pm 0.12 \mathrm{abc}$ & $1.70 \pm 0.09 \mathrm{c}$ \\
$\quad$ (0.66 :0.66: 0.66$)$ & & & \\
Savinase:Bacterial protease: & $99.23 \pm 0.15 \mathrm{a}$ & $5.0 \pm 0.22 \mathrm{abc}$ & $2.10 \pm 0.09 \mathrm{a}$ \\
$\quad$ Pectinase (0.66 : 0.66:0.66) & & & \\
\hline
\end{tabular}

Means with different letters within each column are significant, means followed by the same alphabetical letters are not significantly different at $5 \%$ level and means without letters are not significant. SD : Calculated from values of four replicates. 


\subsubsection{Peroxide value (PV)}

PV indicates the oxidation of the oil. Results in Table 6 show that after pretreatment of CSF with all enzymes and their mixtures the PV increased to different degrees. Statistical data reveal a significant difference between treatments and the control (at $5 \%$ level), as the control had zero PV. Significant difference between some of the treatments could be observed from the results. The increase in $\mathrm{PV}$ ranged from 0.28 to $2.10 \mathrm{meq} / \mathrm{kg}$ oil.

Tano-Debrah and Ohta (1995); Che Man et al. (1996); Hanmoungjiai et al. (2001); Taha et al. (2002); Moreau et al (2004); and others when analyzing oils of different oilseeds arising from the enzymatic hydrolysis of oil cell wall prior to oil extraction reported the oil characteristics including AV, IV, PV to be the same as or better than the conventionally extracted oils.

\subsubsection{Fatty acid composition of oils extracted from enzymatically treated cottonseed flakes}

Table 7 reveals the fatty acid (FA) composition of the oils extracted from enzymatically treated CSF, together with oil extracted from non treated CSF. The results of GLC analysis of oils show slight differences between the FA composition of enzymatically treated oils and untreated oil. Also the difference in the FA composition of oils from different treatments is slight. The ratio between Saturated: Unsaturated (S: US) fatty acids was close for most of the different enzymatically treated oil samples and the control. The ratio of S: US FA was higher for oils resulting $\mathrm{Pa}$ and $\mathrm{S}$ : $\mathrm{Bp}$ treated $\mathrm{CSF}$, being $1: 2.48$ and 1: 2.34, respectively, compared to $1: 2.23$ for untreated oil. These results are in agreement with the work of (Taha et al. 2002) where they reported slight changes or no significant difference between enzymatically treated oils and non treated oils.

\section{CONCLUSION}

It can be said that the enzymatic pretreatment of oilseeds in general, is a safe and efficient tool for increasing the extracted oil yield as well as producing good quality edible oil. Savinase (a protease) either alone or preferably in combination with pectinase, bacterial protease and cellulase, is recommended for the pretreatment of cottonseed flakes under the conditions reported to increase oil yield and preserve oil quality. Although enzymatic pretreatment in this work was followed by solvent extraction of the oil (this was only for convenience) but will be replaced by hydraulic pressing in am up coming study in order to fully achieve the clean technology we are seeking .

\section{REFERENCES}

AOCS 1998. Official methods and recommended practices of the AOCS ( $15^{\text {th }} \mathrm{Ed}$.).

Champaign, IL: AOCS Press.

Bhatnagar S, Johari BN. 1987. Microbial enzymes in the processing of oilseeds. Curr. Sci. 56, 775 - 776.

Carpita NC, Gibeaut DM. 1993. Structural models of primary cell walls in flowering plants: consistency of molecular structure with the physical properties of the cell walls during growth. Plant J. 3, 1-30.

Che Man Y.B, Suhardiyono AB, Asbi, MN, Wei L.S. 1996. Aqueous enzymatic extraction of coconut oil. J. Am. Oil Chem. Soc. 73, $683-686$

Chen BK, Diosady, L.L.2003. Enzymatic aqueous processing of coconut. Int. J. Appl. Sci. Eng., 1, 55-61

Christie W.1973. Lipid Analysis 1st Ed., pp 87-96, Oxford, Pergamon Press.

Dominguez H, Nunez M., Lema JM.1993. Oil extractability from enzymatically treated soybean and sunflower: range of operational variables. Food Chem., 46, 277-284.

Hanmoungjiai P, Pyle DL, Niranjank K. 2002. Enzyme assisted water extraction of oil and protein from rice bran. J. Chem. Technol. Biotechnol.77, 771-776.

Table 7

Fatty Acid Composition of Cottonseed Oil Extracted from Enzymatically Treated Cottonseed Oil.

\begin{tabular}{|c|c|c|c|c|c|c|c|c|}
\hline \multirow{2}{*}{ Enzyme Treatment } & \multicolumn{8}{|c|}{ Fatty Acid Composition \% } \\
\hline & C 14:0 & C 16:0 & C 16:1 & C 18:0 & C 18:1 & C 18:2 & C 18:3 & $\begin{array}{l}\text { Sat: Unsat } \\
\text { ratio }\end{array}$ \\
\hline non (control) & 0.4 & 30 & 0 & 0.5 & 23.6 & 45.2 & 0.3 & $1: 2.23$ \\
\hline Bacterial protease & 0.5 & 29.6 & 0 & 0.4 & 24 & 45.1 & 0.2 & $1: 2.27$ \\
\hline Savinase & 0.3 & 28.4 & 0.3 & 1.4 & 24.5 & 44.9 & 0.2 & $1: 2.28$ \\
\hline Papain & 0.5 & 27.9 & 0.2 & 0.1 & 25.1 & 46.1 & 0.1 & $1: 2.48$ \\
\hline Termamyl & 0.7 & 27.2 & 0.8 & 2.4 & 23.2 & 45.6 & 0.1 & $1: 2.11$ \\
\hline $\begin{array}{l}\text { Savinase : Bacterial } \\
\text { protease }(1: 1)\end{array}$ & 0.2 & 32.1 & 0.1 & 0.2 & 23 & 44.2 & 0.2 & $1: 2.34$ \\
\hline Savinase : Papain (1:1) & 0.4 & 30.1 & 0.3 & 0.3 & 25 & 43.6 & 0.3 & $1: 2.11$ \\
\hline Savinase : Termamyl (1:1) & 0.3 & 30 & 0 & 0.9 & 24.3 & 44.2 & 0.3 & $1: 2.21$ \\
\hline Savinase : Cellulase $(1: 1)$ & 0.5 & 29.9 & 0 & 0.5 & 24.3 & 44.6 & 0.2 & $1: 2.21$ \\
\hline Savinase :Pectinase $(1: 1)$ & 0.3 & 32.2 & 0.2 & 0.1 & 23 & 44 & 0.2 & $1: 2.01$ \\
\hline $\begin{array}{l}\text { Savinase:Cellulase:Pectinase } \\
(0.66: 0.66: 0.66)\end{array}$ & 0.3 & 29.9 & 0 & 0.2 & 24.2 & 45.2 & 0.2 & $1: 2.28$ \\
\hline $\begin{array}{l}\text { Savinase:Bacterial protease: } \\
\text { Pectinase }(0.66: 0.66: 0.66)\end{array}$ & 0.3 & 30.2 & 0.2 & 0 & 24.6 & 44.4 & 0.3 & $1: 2.25$ \\
\hline
\end{tabular}


Hitze W, Stute R, Woelk HU, Gillaue R, Walson P.1972. Enzyme aided extraction of corn germ oil. British Patent 1,402,769.

Lanzani A, Petrini MC, Cozzoli, O, Gallavresi P, Carola C, Jacini C. 1975 . On the use of enzymes for vegetable oil extraction. A preliminary report. La Rivista Italiana Della Sostanze Grasse LII-Loglio, 52, 226 - 229

McGlone OG, Canales AL, Carter JV. 1986. Coconut oil extraction by a new enzymatic process. J. Food Sci., $51,695-697$.

Moreau BA, Johnston DB, Powell MJ, Hicks KB. 2004. A comparison of commercial enzymes for the aqueous enzymatic extraction of corn oil from corn germ. $J$. Am. Oil Chem. Soc. 81, 1071 -1075.

Rosenthal A, Pyle DL, Niragan K, Gilmour S, Trimca L. 2001.Combined effect of operational variables and enzyme activity on aqueous enzymatic extraction of oil and protein from soybean. Enzyme and Microbial Technol. 28, $499-509$.

Santas RD, Ferrari RA .2005. Aqueous enzymatic of soybean oil. Ciencia y Technología de Alimentos 51, 287.

Shankar D, Agrawal YC, Sarkar BC, Singh BPN. 1997. Enzymatic hydrolysis in conjunction with conventional pretreatments to soybean for enhanced oil availability and recovery. . J. Am. Oil Chem. Soc. 74 1543- 1547.

Sharma A, Khare SK, Gupta MN. 2001. Enzyme assisted aqueous extraction of rice bran oil. J. Am. Oil Chem. Soc. 78, 946-949.

Sharma A, Khare SK, Gupta MN. 2002. Enzyme-assisted aqueous extraction of peanut oil. J. Am. Oil Chem. Soc. 79, 215 - 218.

Sengupta R, Bhattacharyya DK. 1996. Enzymatic extraction of mustard seed and rice bran. . J. Am. Oil Chem. Soc. 73, $687-692$.
Sitohy MZ, Badr EH, Perifanova-Nemska, Kadjiski TS.1993. Characterization of enzymatically extracted sunflower seed oil as well as the protein residues. Grasas y Aceites 44, 345 - 347.

Smith DD, Agrawal YC, Sarkar BC, Singh BPN. 1993. Enzymatic hydrolysis pretreatment for mechanical expelling of soybeans. . J. Am. Oil Chem. Soc. 70, 885 $-890$.

Snedecor GW, Cochran WG. 1980. Statistical Methods, $7^{\text {th }}$ Ed., lowa State University Press, lowa, USA.

Sosulski K, Sosulski FW. 1993. Enzyme aided vs. twostage processing of canola. J. Am. Oil Chem. Soc. 70, 825-830.

Snyder HE, Kwon TW.1987. Morphology and Composition In "Soybean Utilization". Snyder and Kwon Eds, pp.19-70 Van Norstrand \& Reinhold Co. Inc., New York.

Taha FS, Youssef EAA, Omar S. 2002. Preliminary studies on the enzymatic treatment of cottonseed for higher oil yield. J. Agric.I Sci. Mansoura University 27, $2794-2808$

Tano-Debrah K, Ohta Y. 1995. Enzyme-assisted aqueous extraction of Shea fat: a rural approach. . J. Am. Oil Chem. Soc. 72, $251-256$.

Walter A, Duncan DB. 1969. Multiple ranges and multiple tests. Biometrics 11, 1-24.

Wang Z, Xu SY, Wang Y. 2004. Aqueous enzymatic extraction from oil and protein hydrolysates from peanut. Proceedings of the IFT annual meeting, July 12-16, Las Vegas, NV.

Recibido: 11/10/06 Aceptado: $11 / 4 / 07$ 